\title{
中国・四川省の元・明代の三間堂に関する研究
}

\section{A STUDY ON THE BUDDHIST BUILDINGS OF THREE BAY TYPE IN SICHUAN PROVINCE, CHINA IN YUAN AND MING DYNASTY}

\author{
曹毅*1, 杉野丞*2, 沢田 多喜二*3, 李 澐 璋*4, 張 葉 茜*5 \\ Yi CAO, Noboru SUGINO, Takiji SAWADA, \\ Yunzhang LI and Yeqian ZHANG
}

\begin{abstract}
In this study, we conducted an on-site survey of 89 temple buildings in Yuan and Ming Dynasty and well-preserved in Sichuan Province, centered on Three bay building type. Next, we took 20 buildings from the Yuan and Ming Dynasty, created a plan view and a cross-sectional view, analyzed the plane dimensions, and compared these plane forms, structural systems, tokyous and design. And the architectural characteristics of the Yuan and Ming Dynasty Three bay building type of the ministry were clarified.
\end{abstract}

Keywords : Sichuan Province, Yuan and Ming Dynasty, Three bay building type, Plane form, Structure, Design 四川省, 元・明代, 三間堂, 平面形式, 構造, 意匠

\section{1. はじめに}

四川省は、中国西南地方の長江上流域にあって山岳地に囲まれた 盆地を形成し、西に標高 $3000 \mathrm{~m}$ 級のチベット高原と横断山脈、北に 秦嶺、東南部に $500 \mathrm{~m} \sim 2000 \mathrm{~m}$ 程の湘鄂西山地と雲貴高原が徱えて おり、盆地には周囲の高原より河川が流れ込み、雅聋江、大渡河、 岷江、嘉陵江などの支流が長江に合流する水系を造っている。

四川省は古代に巴蜀と称され、「巴」は重慶一帯、「蜀」は成都一 帯である。三国時代には、劉備が蜀漢を建て、魏・呉と天下を争っ たが、AD.581 年には隋に支配され、AD. 618 年に唐が成立すると経 済的な最盛期を迎えた。五代十国時代には、前蜀と後蜀が中原支配 を脱し、両蜀一帯に独自の政権を樹立する。その後、宋の支配を受 け、 $\mathrm{AD} .1001$ 年北宋に入ると益州路（現成都）・梓州路（現三台）・ 傹州路（現奉節）・利州路（現広元）の 4 地域が統合され、四川路が 設けられると四川と称されるようになった。そして、利州路は現広 元市から漢中市を所轄して華北地方との交流の要衡となり、揹州路 は長江上流域の重慶市東部で華中地方との交流の要所となり、重慶 市東南部は華南地方と接していたため、四川路は盆地でありながら、 華北・華中・華南の文化を受容し、宋・元・明代の四川路は固有の 文化を生み出すことになった。しかし、明末から清初の張献忠によ る農民蜂起 ${ }^{1)}$ に対する弾圧によって、300 万人余の大量死者を出し たため、古代からの四川の漢族は絶滅したともいわれ、その後の 100 年間程で湖北・湖南 - 広東各省の漢族と少数民族の流入により復興 された2)。

\section{2. 研究目的}

四川省には中国仏教の四大名山の蛾眉山や楽山・凌雲寺大仏、北 山・宝頂山石刻などの仏教遺跡、青城山、青羊宮等の道教寺観など の歴史的な遺産が残され、寺廟建築についても、成都市の大聖慈寺、 峨眉山の万年寺、平武県の報恩寺などの遺構が知られ、仏教・道教 文化を古くから醉成させてきた。しかし、木造建築となると宋代以 前に溯る遺構は少なく、その多くは、元・明代以降に建立されたも のである。それらの遺構については、中国側において個別の建物の 調査がなされているが注 1)、四川省の寺廟建築の地域的な特質に関す る研究は行われていない。そこで、本稿では四川省の元・明代の寺 廟建築の三間堂を取り上げ、平面・構造・意匠について、同省の三 間堂の建築的な特質を明らかにすることを目的とする。

\section{3. 研究方法}

本研究は、四川省の寺院、道観、廟の中から元・明・清代の木造 建築について、国指定の重点文物を中心に省・市指定文物、さらに 保存状態の良い未指定の遺構を加え、文物局の聞き取り調查を行っ て残存状況を把握した。次に、AD.1999 年から AD.2019 年にかけ て調查が許された天王殿、三間堂、五間堂、七間堂、一重裳階付仏 殿等の 89 棟注 ${ }^{2)}$ について、現地調查を行い、実測調查、写真撮影を 実施し、平面図、構造・意匠等の資料を作成した。更に、既往研究 の調查、文献調查 ${ }^{3) \sim 7)}$ を行った。

本稿では、この中から元・明代の三間堂 20 棟を抽出し、中国文物

\footnotetext{
*1 愛知工業大学大学院工学研究科生産建設工学専攻 博士後期課程 $\cdot$ 工修

*2 愛知工業大学工学部建築学科 教授・工博

*3 愛知工業大学工学部建築学科 非常勤講師

*4 四川大学建築与環境学院 教授.工博

*5 南京林業大学風景園林学院 講師・工博
}

Grad. Student, Dept. of Production and Construction Engineering Course, Graduate School of Engineering, Aichi Institute of Technology, M.Eng.

Prof., Dept. of Architecture, Aichi Institute of Technology, Dr.Eng.

Lect., Dept. of Architecture, Aichi Institute of Technology

Prof., Dept. of College of Architecture \& Environment, Sichuan University, Dr.Eng.

Lect., College of Landscape Architecture, Nanjing Forestry University, Dr.Eng. 
局の資料、中国側の論文、さらに現地調查の古記録（寺誌、石碑、 棟木の墨書）から沿革・建立年代等を検証し、断面図と基礎資料を 作成した。なお、 20 棟の遺構は保存状態の良いものを選定し、当初 の姿をよく留めている平面、軸部、斗栱、小屋組等を検討の対象と した。また、AD.1999 年から AD.2019 年までの現地調查の結果は 拙論「中国西南地方の寺廟建築の研究 (1) 〜 (10)」日本建築学会 大会学術講演梗概集 - 同学会東海支部研究報告（AD.2000 年〜 $\mathrm{AD} .2019$ 年) の中で個別の報告を行っている注3)。

\section{4. 四川省の三間堂}

今回取り上げた三間堂の遺構 20 件についてみると、四川省東部 に多く残存し、仏教寺院が 16 件、廟が 2 件、道観が 2 件あり、成 都市の周辺地域に集中し、北東部の徳陽市、綿陽市、南充市、遂寧 市に 12 棟、西南部の眉山市、雅安市、邛崍市に 6 棟、成都市に 2 棟 ある(Fig.1)。建物は、いずれも元・明代に建立され、元代が 5 棟、 明代が 15 棟である(Table1)。そこで、これらの遺構について、1) 平面寸法と柱配列、2）間架と架構システム、3）斗栱と中備、4）登 梁と尾垂木尻に区分して検討する。

\section{4-1. 平面寸法と柱配列}

三間堂 20 棟の平面は、桁行 3 間、梁行 3 間のものが 9 棟、桁行 3 間、梁行 4 間のものが 10 棟、桁行 3 間、梁行 5 間のものが 1 棟 ある (Fig.2)。規模についてみると、最大規模の 4 . 永安寺大殿 ${ }^{8}$ は桁 行 3 間 $(15.19 \mathrm{~m})$ 、梁行 4 間 $(15.41 \mathrm{~m})$ であり、最小規模の 5 .五 龍廟文昌閣は桁行 3 間 $(9.65 \mathrm{~m}) 、$ 梁行 3 間 $(9.66 \mathrm{~m})$ であり、全体 の平均的な規模は、桁行総長 $12.42 \mathrm{~m}$ 、梁行総長 $12.26 \mathrm{~m}$ 程となる。 一方、桁行総長と梁行総長の分布図 (Fig.3) から見ると、三間堂の規 模は 1 辺を $12 \mathrm{~m} \sim 15 \mathrm{~m}$ とするものが一般的であり、平面はほぼ正方 形であることが分かる。但し、6. 百福院前殿、10.饒益寺大雄宝殿、 16. 河沙寺大雄宝殿は桁行と梁行の総長比が $1: 0.9$ 程であり、桁行 が梁行より若干広くなっている。

柱間寸法注 ${ }^{4)}$ についてみると (Table1) 注 5) 、正面柱間（桁行）では 脇間（左脇間）と中間の比率注 $\left.{ }^{6}\right)$ が $1: 1.29$ (20. 文星廟正殿) から 1 : 3.25 (1. 花林寺大殿 $\left.{ }^{9)}\right)$ まであり、平均は $1: 2.28$ である。20 棟の 正面柱間についてみると、脇間 : 中間の比は、文星廟正殿と五龍廟 文昌閣の 2 棟では $1:(1.29 \sim 1.47)$ 、河沙寺大雄宝殿、3.報恩寺三清 殿他の 9 棟では 1 : (1.80 2.26)、12. 甘泉寺大雄宝殿、8. 梓潼宮大 殿他の 3 棟では $1:(2.50 \sim 2.71) 、 15$. 宝梵寺大雄宝殿、花林寺大殿 他の 5 棟では 1 : (2.79 3.25) であり、中間寸法は脇間寸法の約 1.38 倍 ( 2 棟)、約 2.0 倍（10 棟）、約 2.6 倍（3 棟）、約 3.0 倍（5 棟）となっており注7)、中間を脇間の 2.0 倍から 3.0 倍程と広くとる ものが多い点が大きな特徴になっている注 8) 注 9 )。

側面柱間 (梁行) は、 3 間が 9 棟、 4 間が 10 棟、 5 間が 1 棟あり、 3 間乃至 4 間とするものが一般的である。先ず、側面柱間 3 間では、 正面柱間と同様にとるものが五龍文昌閣、百福院前殿他の 7 棟あり、 側面前方柱間を広めたものに 7. 盤陀寺大殿、17.観音寺毘盧殿の 2 棟 がある。これらの前方間：中間（2 間分）：後方間の比率は、前者で は 1 : (1.63〜2.63)：1であり、後者では $1:(1.26 〜 1.31):(0.59 \sim$ 0.60) であり、正面柱間と比べて中間が狭くなっている。次に、側 面柱間 4 間では、正面柱間と同様に中間を広くとって 2 等分するも のが花林寺大殿、2. 青龍寺大殿 ${ }^{10)}$ 他の 7 棟あり、側面前方間を広く

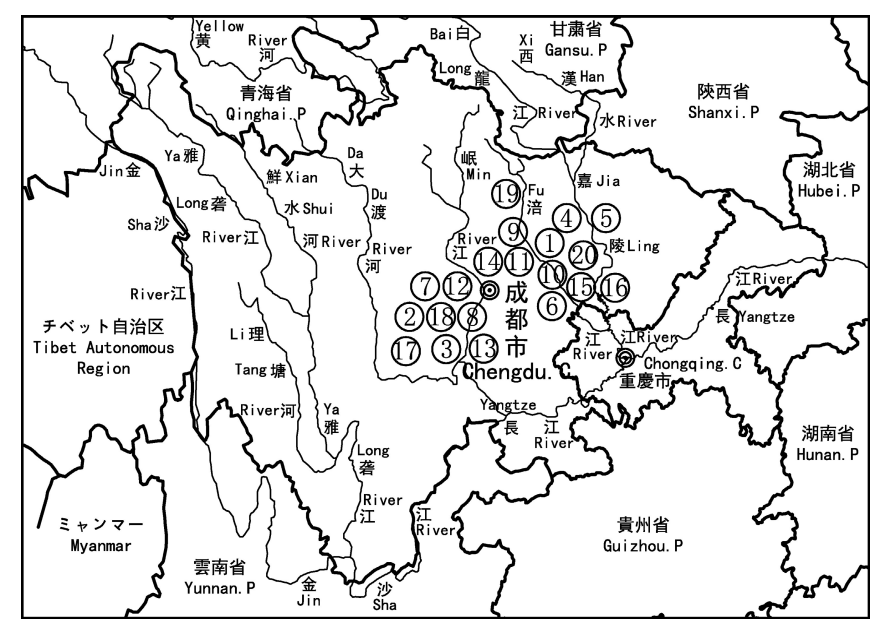

Fig.1 Target article distribution map

取り、中間を 2 等分したものが報恩寺三清殿、9.開禧寺大雄殿の 2 棟ある。これらの前方間 : 中間（2 間分）：後方間の比率は、前者で は 1 : (1.88〜2.99)：(0.98〜1.01) であり、後者では 1 : (1.29〜 1.44) : (0.53 0.71) である。その他、永安寺大殿の側面は $1: 4.60$ : 0.97 である。このように、側面柱間においては中間を 3 間のもので は 2.0 倍から 2.5 倍程、 4 間のものでは 1.5 倍から 3.0 倍程とするも のが多いことが分かる。

一方、三間堂の正面柱間に着目して (Fig.2)を見ると、元代の花林 寺大殿、永安寺大殿、五龍廟文昌の 3 棟と明代の文星廟正殿 1 棟で は正面柱間をいずれも吹放しとしており、元代の遺構では、正面柱 間を吹放す傾向が認められ、三間堂の正面を開放させた点に特徴が ある。

ここで、三間堂 20 棟の外観について眺めておきたい(Tab.2, Fig.2)。屋根は、入母屋造・瓦莫が 19 棟あり（河沙寺大雄宝殿のみ 単層切妻造)、正面隅部の軒反りは緩やかである(Photo1, Photo2)。 垂木は現状で見る限り、一軒の場合、地垂木を平行垂木とし、隅の み扇垂木とするものが 3 棟ある。二軒の場合、地垂木と飛縁垂木の いずれも平行垂木とするものが 10 棟、地垂木と飛縁垂木の隅を扇 垂木とするものが 5 棟あり、開善寺正殿のみが地垂木の隅部を扇垂 木、飛縁垂木を平行垂木とする。垂木の断面形状は、厚板状の長方 形とするものが 15 棟あり、正方形とするものが 3 棟、丸形とする ものが 2 棟ある。鼻隠板については、飛縁垂木先端に設置するもの が 14 棟、設置しないものが 6 棟あり、地垂木先端に設置するもの が 13 棟、設置しないものが 7 棟ある。壁についてみると、大壁式注 10) が 3 棟、真壁式注 ${ }^{11)}$ が 17 棟であり、基壇と礎石についても、基壇 をもつものが 18 棟あるが、いずれも 2 尺以下と低く、礎盤も石製 の円形型とするものが 19 棟あるが、 0.5 尺弱の高さで彫刻も少なく 簡素なものである。

\section{4-2. 間架と架構システム}

中国の寺廟建築の構造形式には、抬梁式と穿闘式の二種類があり、 抬梁式は華北・華中地方に多く、柱上に斗栱をおき、梁と束を交互 に積み上げ、梁の両端に母屋桁を置いて屋根を支える構造であり、 穿斗式は華南地方に多く、柱に穴を穿って貫を通して横方向を固め、 斗栱も差肘木斗栱として梁を用いず、柱頂に母屋桁を載せて屋根を 支える構造である。そこで、三間堂 20 棟の平面図に斗栱、虹梁、梁 


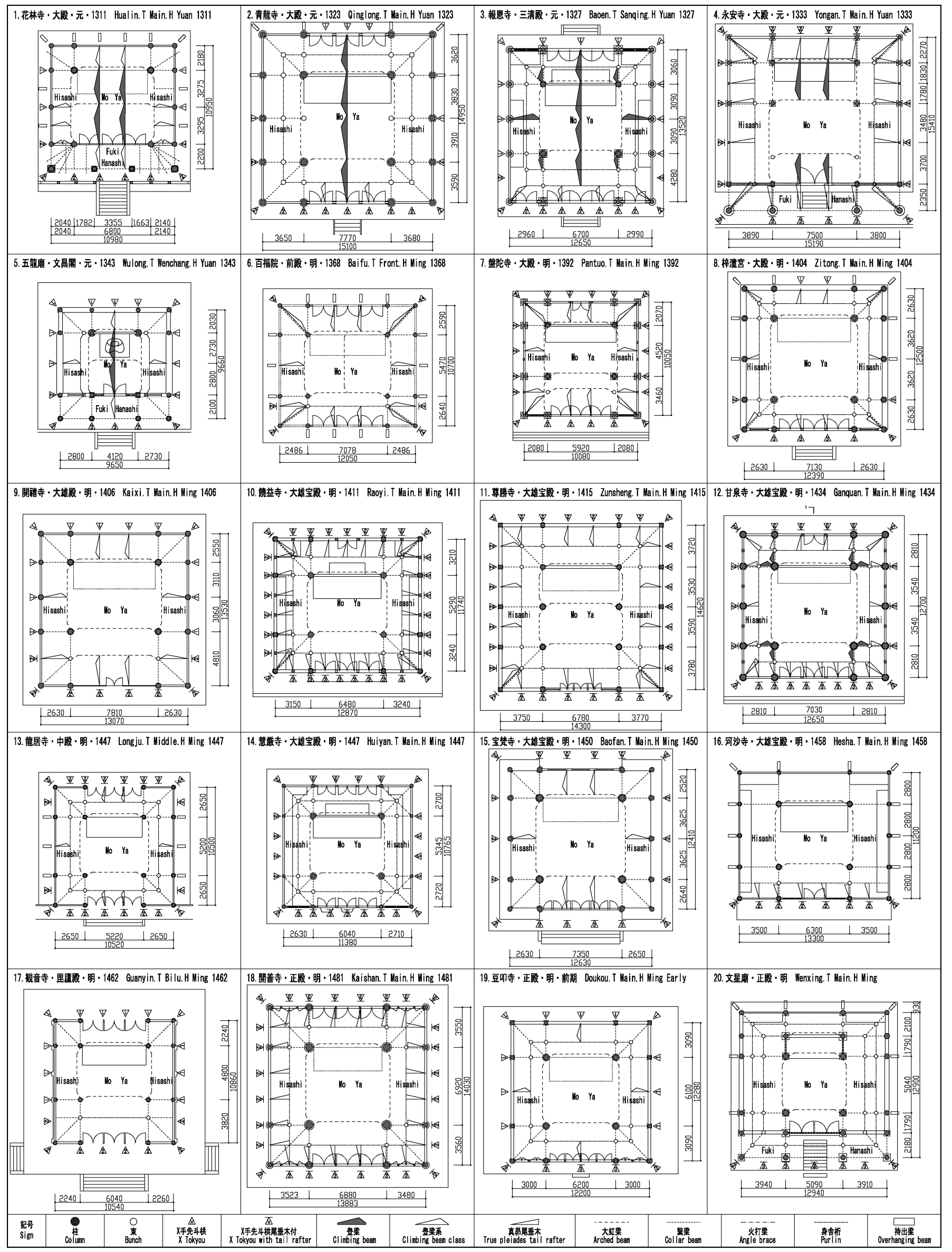

Fig.2 Target article ground plan 
Table1 Plane dimensions list

\begin{tabular}{|c|c|c|c|c|c|c|c|c|c|c|c|c|c|c|c|c|c|c|c|}
\hline & \multirow{4}{*}{$\begin{array}{c}\begin{array}{c}\text { Jf院名 } \\
\text { Tenale } \\
\text { name }\end{array} \\
\begin{array}{c}\text { 花林寺 } \\
\text { Hual in. } T\end{array}\end{array}$} & \multirow{4}{*}{\begin{tabular}{|c|c|c}
$\begin{array}{c}\text { 建築名 } \\
\text { Bui Iding } \\
\text { name }\end{array}$ \\
$\begin{array}{c}\text { 大殿 } \\
\text { Main. H }\end{array}$
\end{tabular}} & \multirow{4}{*}{\begin{tabular}{c|}
$\begin{array}{c}\text { 所在地 } \\
\text { Address }\end{array}$ \\
$\begin{array}{c}\text { 綿陽市 } \\
\text { Mi anyang. C }\end{array}$
\end{tabular}} & \multirow{4}{*}{\begin{tabular}{|c|}
$\begin{array}{c}\text { 建立年代 } \\
\text { The erection } \\
\text { generation }\end{array}$ \\
$\begin{array}{c}\text { 元 } \cdot 1311 \\
\text { Yuan } \cdot 1311\end{array}$ \\
\end{tabular}} & \multirow{4}{*}{ 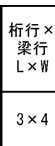 } & \multirow{3}{*}{\begin{tabular}{|c|}
$\begin{array}{l}\text { 析行行紷長 } \\
\text { (m) Length } \\
\text { president }\end{array}$ \\
10.98 \\
\end{tabular}} & \multirow{2}{*}{\begin{tabular}{|l} 
粱行総長 \\
(m) Width \\
president
\end{tabular}} & \multicolumn{3}{|c|}{ 析行 (m) Length } & \multirow{2}{*}{\begin{tabular}{|c|} 
梁行(㑡柱) \\
前方 \\
Front \\
\end{tabular}} & \multicolumn{2}{|c|}{ (m) Width (Side colunn) } & \multicolumn{6}{|c|}{ 梁行 (内柱) (m) Width (Inner column) } \\
\hline & & & & & & & & \begin{tabular}{|c|}
$\begin{array}{c}\text { 有腈間 } \\
\text { Left }\end{array}$ \\
\end{tabular} & \begin{tabular}{|c|} 
中間 \\
Center
\end{tabular} & \begin{tabular}{|l|} 
右勎閣 \\
Right
\end{tabular} & & 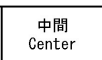 & \multirow{2}{*}{\begin{tabular}{|c|}
$\begin{array}{c}\text { 後方 } \\
\text { Poster ior }\end{array}$ \\
2.18 \\
\end{tabular}} & $\begin{array}{l}\text { 前方 } \\
\text { Front }\end{array}$ & \multicolumn{3}{|c|}{$\begin{array}{c}\text { 中閏 } \\
\text { Center }\end{array}$} & $\begin{array}{c}\text { 後方 } \\
\text { Poster ior }\end{array}$ & \multirow{2}{*}{\begin{tabular}{|c|c|}
$\begin{array}{l}\text { 架楾数 } \\
\text { Rafter } \\
\text { number }\end{array}$ \\
6 6架
\end{tabular}} \\
\hline & & & & & & & 10.95 & 2.04 & 6.80 & 2.14 & & & & 2.20 & 1.65 & 1.64 & 1.64 & 2.18 & \\
\hline & & & & & & 1.00 & 1.00 & 1.00 & 3.33 & 1.05 & 1.00 & \begin{tabular}{|l|l|}
1.50 & 1.49 \\
\end{tabular} & 0.99 & \begin{tabular}{|l} 
架 1 rafters \\
\end{tabular} & 2架 2 rafters & 2架 $2 \mathrm{ra}$ & afters & 1架 1 rafters & \\
\hline & & & & & & 15.10 & 14.95 & 3.65 & 7.77 & 3.68 & 3.59 & \begin{tabular}{|l|l|}
3.91 & 3.83 \\
\end{tabular} & 3.62 & \begin{tabular}{|l|l|}
1.80 & 1.80 \\
\end{tabular} & 1.96 & 1.92 & 1.92 & 1.81 & 8架 \\
\hline & inglong. & $m_{2}$ & & Yuan. 1323 & & 1.00 & 0.99 & 1.00 & \begin{tabular}{|l|}
2.13 \\
\end{tabular} & 1.01 & 1.00 & \begin{tabular}{|l|l|}
1.09 & 1.07 \\
\end{tabular} & 1.01 & \begin{tabular}{|l|l|} 
2架 2 rafters \\
\end{tabular} & 2架 2 rafters & 2架 $2 \mathrm{ra}$ & afters & 2架 2 rafters & raft \\
\hline & 鞦思寺 & & & & & 12.65 & 3.52 & 2.96 & 6.70 & 2.99 & 4.28 & \begin{tabular}{|l|l|}
3.09 & 3.09 \\
\end{tabular} & 3.06 & \begin{tabular}{|l|l|l|}
1.43 & 1.43 & 1.43 \\
\end{tabular} & 1.25 & \begin{tabular}{|l|l|l}
1.23 & 1.2 \\
\end{tabular} & \begin{tabular}{l|l|}
23 & 1.23 \\
\end{tabular} & 1.53 & 10架 \\
\hline & Baoen. T & 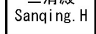 & \begin{tabular}{|l|} 
Mei shan. $\mathrm{C}$ \\
\end{tabular} & 327 & & 1.00 & .07 & 1.00 & 2.26 & 1.01 & 1.00 & \begin{tabular}{|l|l|}
0.72 & 0.72 \\
\end{tabular} & 0.71 & 3架 3 rafters & 2架 2 rafters & 3架 $3 \mathrm{ra}$ & $\frac{1}{\text { afters }}$ & 2架 2 rafters & 0 rafter \\
\hline & & & & & & 15.19 & .41 & 3.89 & \begin{tabular}{|l|l|}
7.50 \\
\end{tabular} & 3.80 & 2.35 & \begin{tabular}{|l|l|}
7.18 & 3.61 \\
\end{tabular} & 2.27 & 2.35 & \begin{tabular}{|l|l|l|}
1.85 & 1.85 & 1.74 \\
\end{tabular} & \begin{tabular}{|l|l|l|}
1.74 & 1.8 \\
\end{tabular} & \begin{tabular}{l|l|}
81 & 1.81 \\
\end{tabular} & 2.27 & \\
\hline & \begin{tabular}{l|l} 
Yongan. $T$ \\
\end{tabular} & 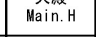 & hong. $c$ & $\begin{array}{ll}\text { Yuan. } 1333 \\
\end{array}$ & & 1.00 & .01 & 1.00 & 1.93 & 0.98 & 1.00 & \begin{tabular}{|l|l|}
3.06 & 1.54 \\
\end{tabular} & 0.9 & \begin{tabular}{|l} 
1 架 1 rafters \\
\end{tabular} & 3架 3 rafters & 3架 $3 \mathrm{raz}$ & afters & 1架 1 rafters & 8 raft \\
\hline & 五能䔕 & 文昌閣 & 充市 & & $3 \times 3$ & 9.65 & 9.66 & 2.80 & 4.12 & 2.73 & 2.10 & 5.53 & 2.03 & 2.10 & \begin{tabular}{l|l|}
1.40 & 1.40 \\
\end{tabular} & 1.37 & 1.37 & 2.03 & 6架 \\
\hline & Wu long. $T$ & ang. $\mathrm{H}$ & tong. $c$ & .1343 & & 1.00 & 1.00 & 1.00 & \begin{tabular}{|l|}
1.47 \\
\end{tabular} & \begin{tabular}{|l|} 
\\
\end{tabular} & 1.00 & 2.63 & 0.97 & \begin{tabular}{|l} 
1架 1 rafters \\
\end{tabular} & 2架 2 rafters & 2架 $2 \mathrm{ra}$ & afters & 1架 1 rafters & raf \\
\hline & & & & & & 12.05 & 10.70 & 2.49 & \begin{tabular}{|l|}
7.08 \\
\end{tabular} & 2.4 & 2.6 & 5.47 & 2.5 & \begin{tabular}{|l|l}
1.32 & 1.32 \\
\end{tabular} & \begin{tabular}{l|l|}
0.90 & 0.90 \\
\end{tabular} & \begin{tabular}{|l|l|}
0.90 & 0.9 \\
\end{tabular} & \begin{tabular}{l|l|}
90 & 1.87 \\
\end{tabular} & 2.59 & \\
\hline & $\begin{array}{l}\text { Brifut } \\
\text { Baifu. T }\end{array}$ & $\begin{array}{l}\text { Front. } \mathrm{H} \\
\text { Frof }\end{array}$ & 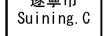 & M & $3 \times 3$ & 1.08 & 89 & 1.00 & 2.85 & 1.00 & 1.00 & 2.07 & 0.98 & \begin{tabular}{|l|} 
2架 2 rafters \\
\end{tabular} & 2架 2 rafters & 3架 $3 \mathrm{ra}$ & afters & 1架 1 rafters & rat \\
\hline & & & & & & 10.0 & 10.05 & \begin{tabular}{|l|}
2.08 \\
\end{tabular} & \begin{tabular}{|l|}
5.92 \\
\end{tabular} & 2.08 & 3.46 & 4.52 & 2.07 & \begin{tabular}{|l|l|l|l}
1.15 & 1.15 & 1.15 \\
\end{tabular} & 1.51 & 1.51 & 1.51 & 1.04 & \\
\hline &.$T$ & Ma & i. 0 & & $3 x^{3}$ & 1.00 & . & 1.00 & 2.85 & 1.00 & 1.00 & 1.31 & 0.60 & \begin{tabular}{|l|l} 
3n 3 rafters \\
\end{tabular} & 1架 1 rafters & 2架 $2 \mathrm{ra}$ & afters & 2架 2 rafters & \\
\hline & 梓 & & 眉山市 & 明. 1404 & & 12.3 & 12.50 & 2.63 & 7.13 & 2.63 & 2.63 & \begin{tabular}{|l|l|}
3.62 & 3.62 \\
\end{tabular} & 2.63 & 1.32 & 1.81 & 0.90 & 0.90 & 1.32 & 8 驾 \\
\hline 8 & & & & & 3 & 1 & 01 & 1.00 & 2.71 & 00 & 1.00 & \begin{tabular}{|l|l|}
1.38 & 1.38 \\
\end{tabular} & 1. & \begin{tabular}{|l} 
2架 2 rafters \\
\end{tabular} & 2架 2 rafters & 2架 $2 \mathrm{ra}$ & afters & 2架 2 rafters & \\
\hline & 開禧寺 & 大雄殿 & & & & 13.07 & 13.53 & \begin{tabular}{|l|}
2.63 \\
\end{tabular} & 7.81 & 2. & 4.81 & \begin{tabular}{|l|l|}
3.06 & 3.11 \\
\end{tabular} & 2.55 & \begin{tabular}{|l|l}
2.55 & 2.26 \\
\end{tabular} & 1.96 & 1.96 & 2.26 & 2.55 & 6架 \\
\hline & Kaixi.T & Main. $\mathrm{H}$ & & & $3 \times 4$ & 1.00 & 04 & 1.00 & \begin{tabular}{|l|}
2.97 \\
\end{tabular} & 1. & 1.00 & \begin{tabular}{|l|l|}
0.64 & 0.65 \\
\end{tabular} & 0.53 & 2架 2 rafters & 1架 1 rafters & 2架 $2 \mathrm{ra}$ & afters & 1架 1 rafters & raft \\
\hline & 触萣寺 & 大椎宝殷 & 㜔市 & 明 $\cdot 1411$ & & 12.87 & 11.74 & 3.15 & \begin{tabular}{|l|}
6.48 \\
\end{tabular} & 3. & 3.24 & 5.29 & 3.21 & \begin{tabular}{|l|l|}
1.62 & 1.62 \\
\end{tabular} & 1.33 & 1.33 & 1.33 & \begin{tabular}{l|l|}
1.61 & 1.61 \\
\end{tabular} & 8架 \\
\hline 10 & $\begin{array}{l}\text { Raovi. T } \\
\text { Retis }\end{array}$ & Main.H & Suining. & $\mathrm{Mi}_{\mathrm{i}}$ & & 1.00 & 0.91 & 1.00 & 2.06 & 1.03 & 1.00 & 1.63 & 0.99 & \begin{tabular}{|l|} 
2架 2 rafters \\
\end{tabular} & 2架 2 rafters & 2架 $2 \mathrm{ra}$ & afters & 2架 2 rafters & $\begin{array}{l}\text { rafters } \\
\text { raf }\end{array}$ \\
\hline & 尊膡寺 & 大椎宝殿 & 榊陽市 & 明 $\cdot 1415$ & & 14. 30 & 62 & 3.75 & \begin{tabular}{|l|}
6.78 \\
\end{tabular} & 3.77 & 3.78 & \begin{tabular}{|l|l|}
3.59 & 3.53 \\
\end{tabular} & 3.72 & \begin{tabular}{|l|l}
1.89 & 1.89 \\
\end{tabular} & 1.80 & 1.77 & 1.77 & \begin{tabular}{l|l}
1.86 & 1.86 \\
\end{tabular} & 8架 \\
\hline & unsheng. & Main. $H$ & Mi anyang. $C$ & Mi & & 1.0 & 02 & 1.00 & 1.81 & 1.01 & 1.00 & \begin{tabular}{|l|l|}
0.95 & 0.93 \\
\end{tabular} & 0.98 & 2架 2 rafters & 2架 2 rafters & 2架 $2 \mathrm{ra}$ & afters & 2架 2 rafters & rafters \\
\hline & 甘泉寺 & 大椎穻段 & 青山市 & 34 & & 12.65 & 12.70 & 2.81 & \begin{tabular}{|l|}
7.03 \\
\end{tabular} & 2.81 & 2.81 & \begin{tabular}{|l|l|}
3.54 & 3.54 \\
\end{tabular} & 2.81 & \begin{tabular}{|l|l|}
1.41 & 1.41 \\
\end{tabular} & 1.77 & 1.77 & 1.77 & \begin{tabular}{l|l}
1.41 & 1.41 \\
\end{tabular} & 8架 \\
\hline & Ganquan. T & Main. & Mei shan. $\mathrm{C}$ & " & & 1 & 1.00 & \begin{tabular}{|l|}
1.00 \\
\end{tabular} & \begin{tabular}{|l|}
2.50 \\
\end{tabular} & 1.00 & 1.00 & \begin{tabular}{|l|l|}
1.26 & 1.26 \\
\end{tabular} & 1.00 & \begin{tabular}{|l|} 
2架 2 rafters \\
\end{tabular} & 2架 2 rafters & 2架 $2 \mathrm{ra}$ & afters & 2架 2 rafters & raft \\
\hline & 能居寺 & & & & & 10.5 & $10 . \mathrm{s}^{2}$ & \begin{tabular}{|l|}
2.65 \\
\end{tabular} & \begin{tabular}{|l|}
5.22 \\
\end{tabular} & 2. & 2.6 & 5.20 & 2. & \begin{tabular}{|l|l|}
1.45 & 1.20 \\
\end{tabular} & 1.30 & 1.30 & 1.30 & \begin{tabular}{l|l|}
1.20 & 1.45 \\
\end{tabular} & \\
\hline 13 & $\begin{array}{l}\text { Longiu. T } \\
\text { Long }\end{array}$ & die. $H$ & genan.c & H & & 1.00 & 1.00 & \begin{tabular}{|l|l|} 
& \\
\end{tabular} & \begin{tabular}{|l|}
1.97 \\
\end{tabular} & 1.00 & 1.00 & 1.96 & 1.00 & \begin{tabular}{|l|} 
2架 2 rafters \\
\end{tabular} & 2架 2 rafters & 2架 $2 \mathrm{ra}$ & afters & 2架 2 rafters & raft \\
\hline & & & & & & 11 & 10. & \begin{tabular}{|l|}
2.63 \\
\end{tabular} & \begin{tabular}{|l|l|}
6.04 \\
\end{tabular} & 2.71 & 2.7 & 5.35 & & 1.36 & 1.34 & 1.34 & 1.34 & 1.35 & \\
\hline & $\begin{array}{l}\text { Huivan. } T \\
\text { Huive }\end{array}$ & 然 & gi. 0 & & & 1.0 & 0.95 & 1.00 & 2.30 & 1.03 & 1.00 & 1.97 & 0.99 & 2架 2 rafters & 2架 2 rafters & 2架 $2 \mathrm{ra}$ & afters & 2架 2 rafters & raft \\
\hline & 宝榃寺 & 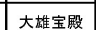 & 廷型 & & & & & 2.63 & 7.35 & 2. & 2.6 & \begin{tabular}{|l|l|}
3.63 & 3.63 \\
\end{tabular} & & 2.64 & 1.81 & 1.81 & 1.81 & 2.52 & \\
\hline & Baofan. T & Main. $H$ & Suining. $c$ & & & 1.00 & 0.98 & 1.00 & 2.79 & 1. & 1.00 & \begin{tabular}{|l|l|}
1.37 & 1.37 \\
\end{tabular} & 0.9 & \begin{tabular}{|l|l} 
架 1 rafters \\
\end{tabular} & 2架 2 rafters & 2 架 $2 \mathrm{ra}$ & afters & 1架 1 rafters & \\
\hline 16 & & & 纹 & & & & & 3.50 & \begin{tabular}{|l|}
6.30 \\
\end{tabular} & & 2.80 & \begin{tabular}{|l|l|}
2.80 & 2.80 \\
\end{tabular} & & \begin{tabular}{|l|l|}
1.40 \\
\end{tabular} & \begin{tabular}{|l|l|}
1.40 & 1.40 \\
\end{tabular} & 1.40 & 1.40 & \begin{tabular}{l|l|}
1.40 & 1.40 \\
\end{tabular} & \\
\hline & Hesha. T & is & chengdu. $\mathrm{c}$ & M & & 1.00 & 0.84 & 1.00 & 1.80 & 1.00 & 1.00 & \begin{tabular}{|l|l|}
1.00 & 1.00 \\
\end{tabular} & 1.00 & 2架 2 rafters & 2架 2 rafters & 2架 $2 \mathrm{ra}$ & afters & 2架 2 rafters & 8 rafters \\
\hline & & & & & & 10.5 & & 2.24 & \begin{tabular}{|l|}
6.04 \\
\end{tabular} & 2. & 3.82 & 4.80 & 2.24 & \begin{tabular}{|l|l|}
1.91 & 1.91 \\
\end{tabular} & 1.60 & 1.60 & 1.60 & 2.24 & \\
\hline & Guany in. T & Bi & du. $c$ & \begin{tabular}{|l|l|} 
Ming $\cdot 1462$ \\
\end{tabular} & & 1. & 03 & 1.00 & 2.70 & 1.01 & 1.00 & 1.26 & 0.59 & \begin{tabular}{|l} 
2架 2 rafters \\
\end{tabular} & 1架 1 rafters & 2架 $2 \mathrm{ra}$ & afters & 1架 1 rafters & 6 rafters \\
\hline 18 & & & & & & 13. & 14 & 3.52 & \begin{tabular}{|l|}
6.88 \\
\end{tabular} & 3. & 3.56 & 6.92 & 3.55 & \begin{tabular}{|l}
1.78 \\
\end{tabular} & 1.73 & 1.73 & 1.73 & \begin{tabular}{l|l|}
1.78 & 1.78 \\
\end{tabular} & \\
\hline & n. 7 & Ma & & Mi & & 1. & 1.01 & 1.00 & 1.95 & 0. & 1.00 & 1.94 & 1.00 & \begin{tabular}{|l} 
2架 2 rafters \\
\end{tabular} & 2架 2 rafters & 2架 $2 \mathrm{ra}$ & afters & 2架 2 rafters & 8 rafters \\
\hline & & & & & & 12. & 1228 & 3.00 & 6.20 & 3. & 3.09 & 6.10 & 3.6 & 1.88 & 1.45 & 1.45 & 1.60 & 1.21 & \\
\hline & Doukou. T & & & & & 1.00 & 1.01 & 1.00 & 2.07 & 1.0 & 1.00 & 1.97 & 1.00 & 2架 2 rafters & 2架 2 rafters & 2架 $2 \mathrm{ra}$ & afters & 2架 2 rafters & 8 rafters \\
\hline & & & & & & 12. & 12. & \begin{tabular}{l|l|}
3.94 \\
\end{tabular} & \begin{tabular}{|l|}
5.09 \\
\end{tabular} & 3.91 & \begin{tabular}{|l|l|}
2.18 & 1.79 \\
\end{tabular} & 5.04 & \begin{tabular}{|l|l|}
1.79 & 2.10 \\
\end{tabular} & \begin{tabular}{|l|l|l|}
1.09 & 1.09 & 1.79 \\
\end{tabular} & \begin{tabular}{l|l|}
1.26 & 1.26 \\
\end{tabular} & 1.26 & 1.26 & \begin{tabular}{|l|l|l|}
1.79 & 1.05 & 1.05 \\
\end{tabular} & \\
\hline & & & & Ming & & 1.0 & & 1.00 & 1. 29 & 0.99 & & 2.31 & 0.96 & 3架 3 & fters & 2架 2 & fters & $\frac{1}{\text { afters }}$ & \\
\hline
\end{tabular}

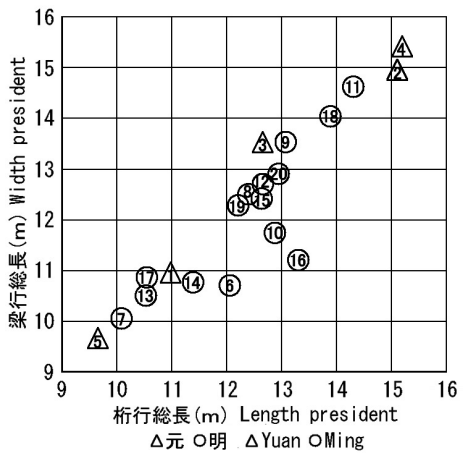

Fig.3 Length of a crossbeam beam line distribution map

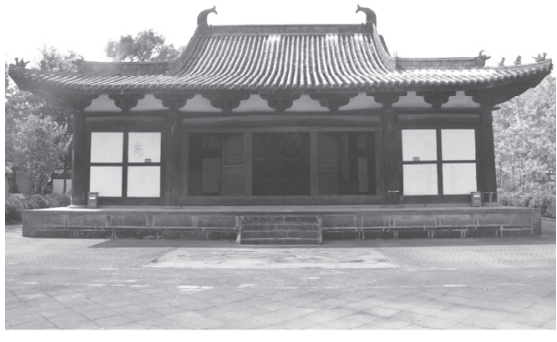

Photo1 2. Qinglong temple main hall exterior photo

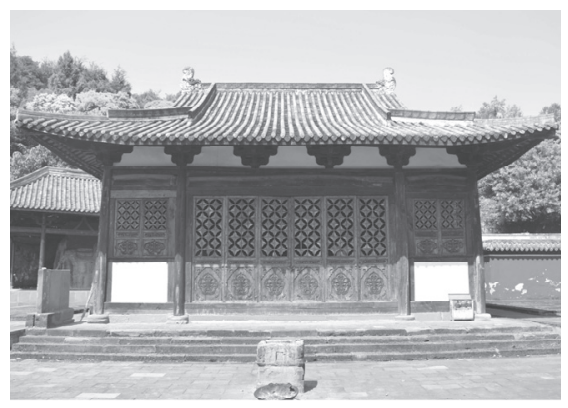

Photo2 7. Pantuo temple main hall exterior photo
組等を表示すると (Fig.2)のようになる。これを見ると、20 棟の遺 構は穿闘式の影響が認められるものの基本的に抬梁式であり、華北・ 華中地方の架構形式に属していることが分かる。さらに、この中か ら内部空間の特徽を探ってみると、20 棟の内 18 棟は主屋中央に身 舎柱 4 本を立て (4. 永安寺大殿、11. 尊勝寺大雄宝殿 ${ }^{11}$ は 6 本)、周 囲に柱間 1 間の庇を巡らしている。そこで、主屋と庇の架構形式を 把握するため、堂内を庇部分と主屋部分に分け、「間架（母屋桁の間 隔)」と側柱の斗栱上部に渡される繋梁の架構システムについて検討 してみたい注 12)
先ず、庇部分について、庇屋根を支える「間架」を基準とし、母 屋桁の一つの間隔を一架として、母屋桁を支える架構システムを検 討寸ることとし、それらの規模を分類してみると、庇一架系（四面

一架、正背面一架 ・両側面二架、正面二架・両側背面一架)、庇二架 系 (四面二架、正面三架・両側背面二架) と庇三架系 (四面三架) の 3 種に分けられる注 13$) 。$

庇一架系には 3 パターンある。四面一架では、身舎柱と隅側柱が 真隅 $\left(45^{\circ}\right.$ 方向）となるため、身舎柱から側柱に桁行、梁行、隅行 の 3 方向 (Photo3) に繫梁を架けており（1. 花林寺大殿、15.宝梵寺大 


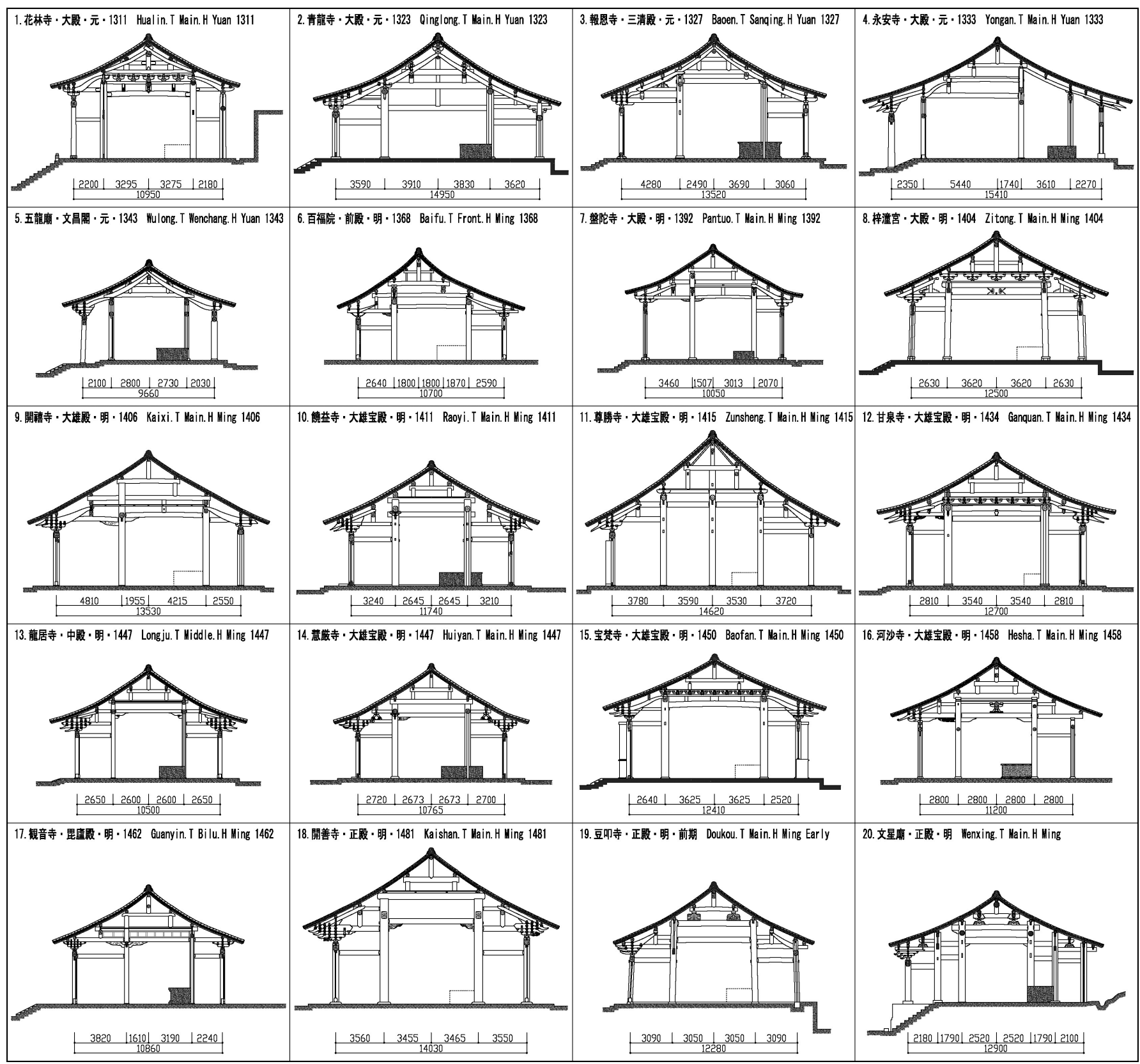

Fig.4 Target article sectional view (Front is Left side)

雄宝殿)、正背面一架・両側面二架では、振れ隅となるため、身舎柱 から側柱に桁行と梁行方向に繋梁を架け、桁行繋梁の内側三分の一 程の位置に束を立て、側柱に隅行方向の繫梁を架け、束上に梁行方 向の母屋桁を通し、屋根を支えている (4. 永安寺大殿、5.五龍廟文昌 宮）（Photo4）。正面二架・両側背面一架とするものは 5 棟ある（6. 百福院前殿、7.盤陀寺大殿、9. 開禧寺大雄殿、16. 河沙寺大雄宝殿、 17.観音寺毘盧殿)。これらは、後方身舎柱では側柱に桁行、梁行、 隅行の 3 方向に繋梁を架け（盤陀寺大殿・河沙寺大雄宝殿は桁行、 梁行の 2 方向)、前方身舎柱では側柱に桁行、梁行の 2 方向に繋梁 を架けており、梁行の繋梁の内方に桁行方向の大虹梁を架けるもの (盤陀寺大殿、開禧寺大雄殿) と無いもの（百福院前殿、河沙寺大 雄宝殿、観音寺毘盧殿）がある。さらに、梁行の慗梁の略中央に束 を立て、桁行、隅行の 2 方向に繋梁を渡寸もの（観音寺毘盧殿）、隅 行方向のみのもの (百福院前殿、開禧寺大雄殿)、梁行方向のみのも
の（河沙寺大雄宝殿）があり、いずれもその交点に束を立て、その 上に桁行方向の母屋桁を通し、屋根を支えている。

庇二架系には 2 パターンある。四面二架では身舎柱から側柱の桁 行、梁行、隅行方向に繋梁を架け、 3 方向の繋梁の中央に束を立て、 上に母屋桁を通し、屋根を支えている (2. 青龍寺大殿、8. 梓潼宮大殿、 10. 饒益寺大雄宝殿、11. 尊勝寺大雄宝殿、12. 甘泉寺大雄宝殿 $<$ 隅行 方向繋梁無し > 13. 龍居寺中殿、14.慧厳寺大雄宝殿、18.開善寺正 殿＜隅行方向繋梁無し＞、19.豆吒寺正殿）（Photo5）。正面三架・両 側背面二架では、後方身舎柱から側柱の桁行、梁行、隅行の 3 方向 に繋梁を架け、繋梁の中央に束を立て、その上に母屋桁を通し、屋 根を支え、前方身舎柱から側柱の桁行、梁行に繋梁を架け、桁行方 向の繋梁中央に束を一具、梁行方向の繋梁三等分の位置に束一具を 立て、上に母屋桁を通し、屋根を支えるものである（3. 報恩寺三清 殿)。 


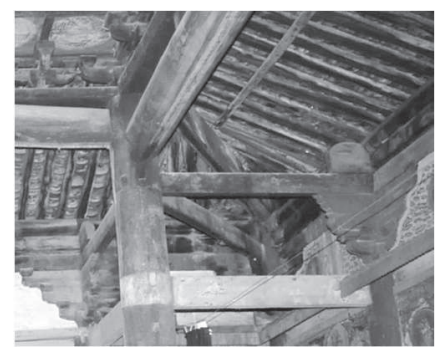

Photo3 15. Baofan temple main hall column top connection beam

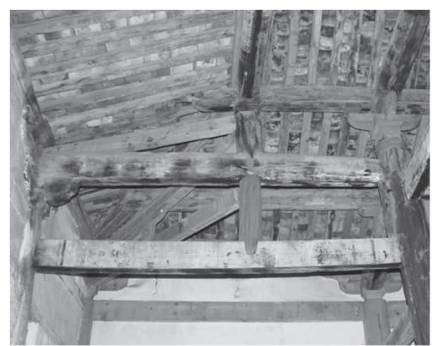

Photo4 4. Yongan temple main

hall column top connection beam

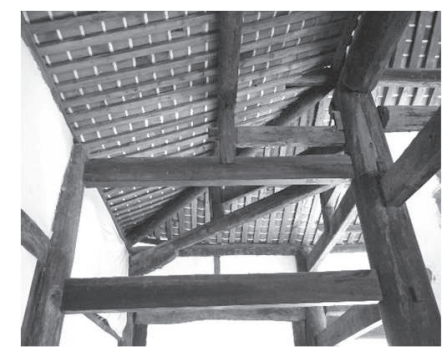

Photo5 2. Qinglong temple main hall column top connection beam

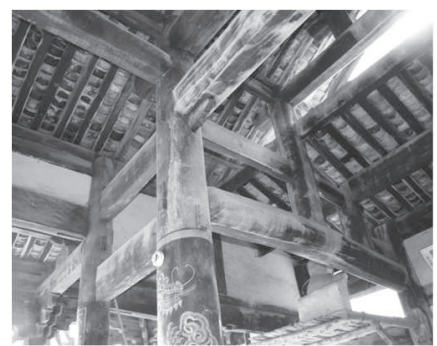

Photo6 20. Wenxing temple main hall column top connection beam
庇三架系には 1 パターンある。四面三架では、身舎柱から両外側 の桁行方向に繋梁を架け、繋梁中央及び内から外側四分の三程の位 置に束を立て、外側梁行方向の柱に繋梁を架け、更にこの柱から桁 行、梁行方向に繋梁を架け、繋梁の中央に彫刻材を入れ、その束上 に母屋桁を通し、屋根を支えるものが 1 棟ある（20.文星廟正殿） (Photo6)。なお、これらの架構システムにおける繋梁上の束には、 安定を計るための小梁が身舎柱から渡されている。

次に、主屋部分について、20 棟の梁行の断面図を一覧すると (Fig.4)のようになる。これを基に、庇部分と同様に間架による分類 を行うと、主屋では三架系、四架系、五架系の 3 種に分けられる。 主屋三架系は 3 棟（7.盤陀寺大殿、9.開禧寺大雄殿、17.観音寺毘盧 殿) あり、これらの断面構成について (Fig.2) と (Fig.4)を眺めると、 いずれも主屋中央の棟木を中心とし、前方一架・後方二架の構成と なるため、前後の身舎柱が建物の中央軸に対し、前後対称とはなら ない。主屋四架系は 15 棟（1. 花林寺大殿、2.青龍寺大殿、5.五龍廟 文昌閣他）あり、この内前方二架・後方二架の構成とするものが 14 棟と最も多く、4. 永安寺大殿のみが前方三架・後方一架の構成とす る。主屋五架系は前方二架・後方三架とするもので 2 棟（3. 報恩寺 三清殿、6.百福院前殿）ある。このように、四川省の三間堂の間架 と架構は、庇二架系、主屋四架系のものが多く、主屋の身舎柱から 側柱に架けて、桁・梁・隅行 3 方向の繋梁を渡し、振れ隅となるも のでは、繋梁上に束を立てて母屋桁を支える架構形式が一般的であ ることが分かる。

一方、三間堂 20 棟の構造について、『営造法式』12)13) 大木作の側 様図と対比させ、主屋と庇から見た断面図を基に間架と柱の本数を 示寸と、「六架椽屋・四柱」が 5 棟（花林寺大殿、五龍廟文昌閣、開 禧寺大雄殿、宝梵寺大雄宝殿と観音寺毘盧殿)、「八架椽屋・四柱」 が 11 棟（青龍寺大殿、百福院前殿、盤陀寺大殿、梓潼宮大殿、饒益 寺大雄宝殿、甘泉寺大雄宝殿、龍居寺中殿、慧厳寺大雄宝殿、河沙 寺大雄宝殿、開善寺正殿、豆吒寺正殿）、「八架椽屋・五柱」が 1 棟 (尊勝寺大雄宝殿)、「八架椽屋・六柱」が 1 棟（永安寺大殿）、「十 架侬屋・四柱」が 1 棟（報恩寺三清殿）、「十架椽屋・六柱」が 1 棟 (文星廟正殿) ある。このように「六架椽屋・四柱」と「八架椽屋・ 四柱」が一般的であるが、断面寸法を見ると (Fig.4)、堂内の一架椽 の寸法が統一されておらず、庇部分では、大木作の六架椽屋側様図 に見られる二重梁（劄链・乳栿）と斜材（拖脚）を用いる方式は姿 を消し、大瓶束で母屋桁を支えるもの、斗栱から内方に延びる尾垂 木尻で母屋桁を支える方式が主流になっており、四川省の三間堂の 架構システムは宋代の木造の伝統的な手法との共通性をもちつつ、 元・明代にはその姿を変えて、固有の構造形式を形成したとみられ
る。但し、営造法式との関連性については、今後三間堂のみならず 他の遺構を含めて検討したい。

\section{$4-3$. 斗栱と中備}

斗栱は斗と栱（肘木）によって構成されるものであり、中国伝統 的な木造建築の重要な要素である。三間堂 20 棟の斗栱を眺めると、 大きな特徴が認められる。中国の寺廟建築において、華北・華中地 方の抬梁式の伝統を引き継ぐ三間堂では、正側背 4 面に同一の斗栱 を巡らすのが正統的な形式である。しかし、四川省の三間堂では三 手先・二手先・一手先（出三斗を含む）・持出梁の 4 種類の斗栱を使 い分けており、半数以上の遺構が斗栱配列を変えている点に特徴が ある。そこで、全 20 棟の斗栱配列を一覧すると、次の 4 タイプに 分類される (Fig.2, Table2)。

1）のタイプは、正面柱上斗栱（付中備）に三手先、両側背面に三 手先・二手先・一手先 (出出三斗を含む) ・持出梁等を用いるもの (4. 永安寺大殿、8. 梓潼宮大殿、19.豆吒寺正殿、20. 文星廟正殿)。2）の タイプは、正面柱上斗栱（付中備）に二手先、両側背面に二手先・ 一手先・持出梁等を用いるも（1. 花林寺大殿、2.青龍寺大殿、3.報恩 寺三清殿、5.五龍廟文昌閣、6.百福院前殿、9. 開禧寺大雄殿、16.河 沙寺大雄宝殿、17.観音寺毘盧殿)。3）のタイプは、正側背 4 面の柱 上斗栱 (付中備) に三手先を用いるもの（10.饒益寺大雄宝殿、12.甘 泉寺大雄宝殿、14.慧篇寺大雄宝殿、15. 宝梵寺大雄宝殿、18.開善寺 正殿）。4）のタイプは、正側背 4 面柱上斗栱（付中備）に二手先を 用いるもの（7.盤陀寺大殿、11.尊勝寺大雄宝殿）である。

このように、三間堂の斗栱配列には 4 面の斗栱を統一させるもの と不統一とするものがあるが、後者は正面柱上斗栱に三手先・二手 先を用い、両側背面の斗栱の手先を減じることで、正面性を高めて いる点では一致している。また、中備の配列についてみると、前述 のように正面柱間では中間を脇間の 2 倍〜 3 倍と広くとるものが多 いため、タイプ 1）では、両側背面の斗栱の手先を減じながらも、 正面柱列中備には中間に 2 具乃至 1 具の詰組を入れるのが一般的で あり、タイプ 2)・3）・4） では詰組を中間 4 具、脇間 1 具とするも の（饒益寺大雄宝殿、甘泉寺大雄宝殿）、中間 3 具、脇間 1 具とする もの（青龍寺大殿、報恩寺三清殿、慧厳寺大雄宝殿）などがあり、 正面柱間に詰組斗栱を多用することで、正面性を一層高めている。

一方、尾垂木の使用についてみると、三手先では大半が擬似尾垂 木注 14) を用い、前方に渦形の尾垂木端を突出させており（饒益寺大 雄宝殿、甘泉寺大雄宝殿、慧㛜寺大雄宝殿、宝梵寺大雄宝殿、開善 寺正殿、豆吒寺正殿、文星廟正殿)、二手先でも半数程が擬似尾垂木 を用い、渦形の尾垂木端を出している（開禧寺大雄殿、尊勝寺大雄 宝殿、龍居寺中殿、河沙寺大雄宝殿)。しかし、元代の永安寺大殿で 
Table2 The buddhist buildings of three bay type design list

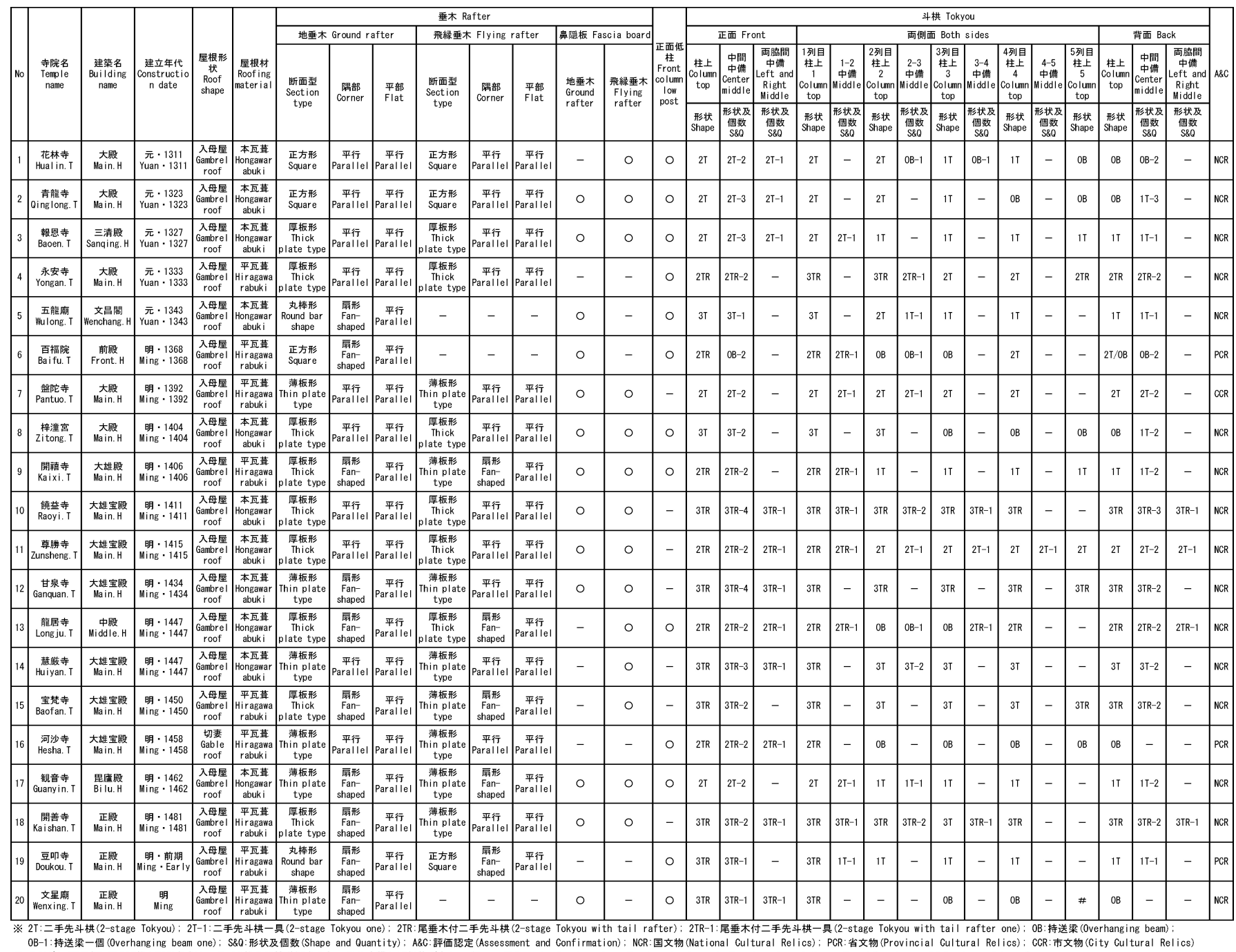

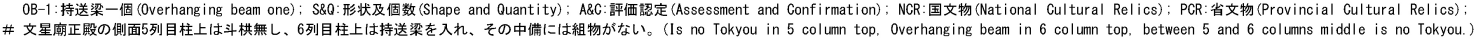

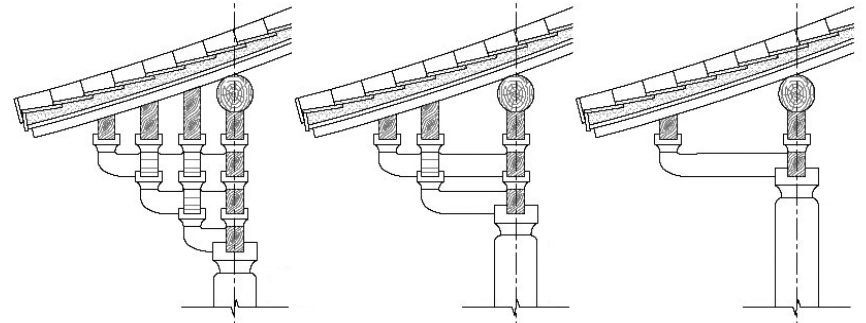

Fig.5 Side tokyou model cross section

は前面斗栱の尾垂木の先端を鋭角に切り出し、三段に連䄈て前方に 出すなど古式な真昂尾垂木注 ${ }^{15)}$ を用いている点が注目される。

ここで、斗栱配列に三手先・二手先・一手先（出三斗を含む）・持 出梁を採用したことで生じた $2 つ の$ 問題点について指摘しておきた い。1 つ目は、斗栱を水平方向から眺めた場合、軒の出を支える斗 栱の肘木の長さを調整する必要がある。三手先では柱真から軒の出 を 3 列外に差し出寸が、二手先・一手先では 2 列・ 1 列となり、肘 木が短くなるため、手先を減じた斗栱では肘木を長く延して、軒先 の通し肘木を支える工夫を行っている (Fig.5)。2つ目は、斗栱を垂 直方向から眺めた場合、三手先 ・二手先 ・一手先 ・持出梁の斗栱の
高さを調整する必要がある。そこで、三間堂の側面を眺めることと し、4 つの事例（饒益寺大雄宝殿、五龍廟文昌閣、花林寺大殿、龍 居寺中殿）を取り上げてみると（Fig.6 9)、饒益寺大雄宝殿は、三 手先を柱上と中備（中間 2 具、脇間 1 具）に等間隔に配しており、 抬梁式の架構の一般的な斗栱配列としている (Fig.6)。しかし、五龍 廟文昌閣は、前方 1 列目柱上に三手先、 2 列目に二手先、 $3 \cdot 4 \cdot 5$ 列 目に一手先（出三斗）を用いており、これらの事例では斗栱の高さ の違いを柱高によって調整しており (Fig.5)、柱間に通る飛貫、頭貫 などを段違いに渡している (Fig.7)。花林寺大殿注 16)では、前方 1 列 目と 2 列目の柱上に二手先を用い、 $3 \cdot 4 \cdot 5$ 列目に一手先 (出三斗) を用いており、柱間の頭貫を段違いに渡している (Fig.8)。龍居寺中 殿でも、前方 1 列目柱上と中備ならびに 4 列目と中備に三手先を用 い、 $2 \cdot 3$ 列目では柱高を高めて、柱上と中備に一手先（出三斗）を 用い、両脇間の頭貫・台輪と中間の大梁を段違いに渡している (Fig.9)。このように、四川省の三間堂では斗栱配列の不統一に対し、 軒の出の違いを肘木の長さにより、斗栱の高さの違いを柱の高さに より調整していることが分かる。

\section{$4-4$. 登梁と尾垂木尻}

四川省の三間堂の中には、屋根裏に構造材として曲材（登梁）を 


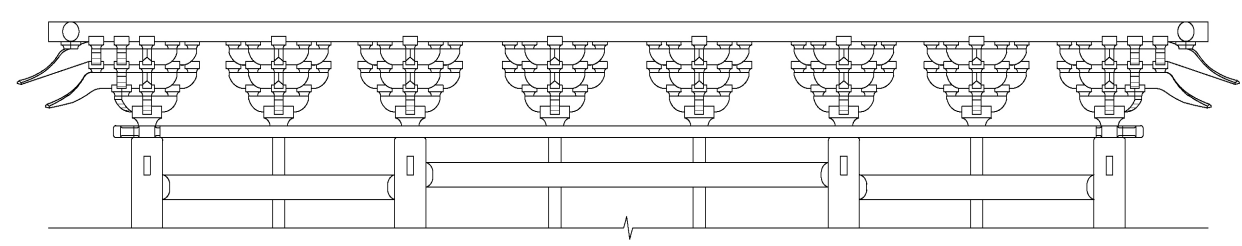

Fig.6 10. Raoyi temple main hall side tokyou elevation

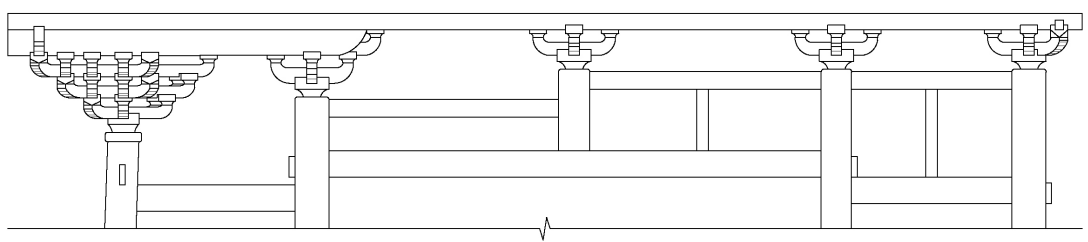

Fig.7 5. Wulong temple wenchang hall side tokyou elevation

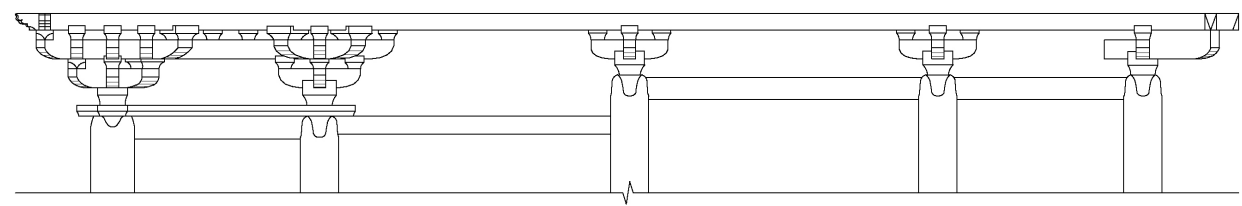

Fig.8 1. Hualin temple main hall side tokyou elevation

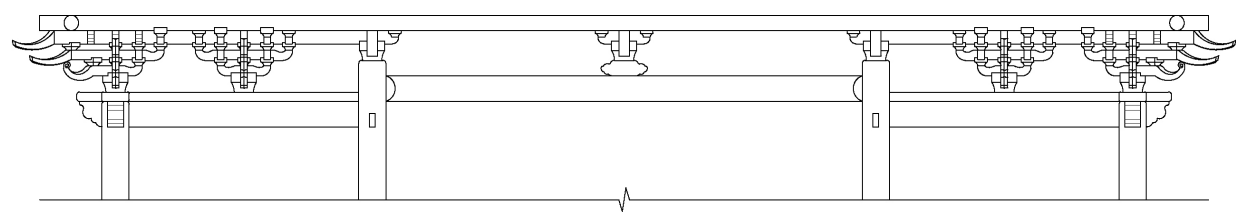

Fig.9 13. Longju temple middle hall side tokyou elevation

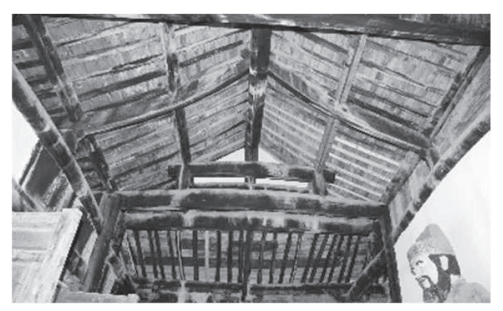

Photo7 5. Wulong temple wenchang hall climbing beam

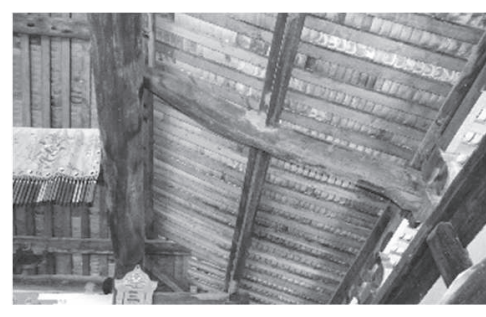

Photo8 3. Baoen temple sanqing hall climbing beam class

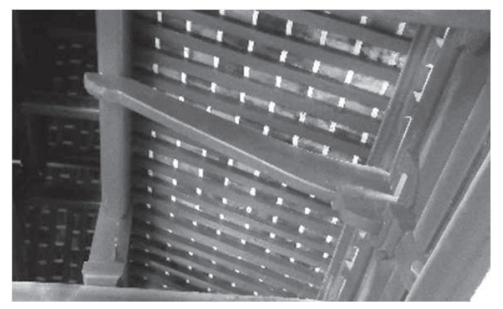

Photo9 11. Zunsheng temple main hall climbing beam class

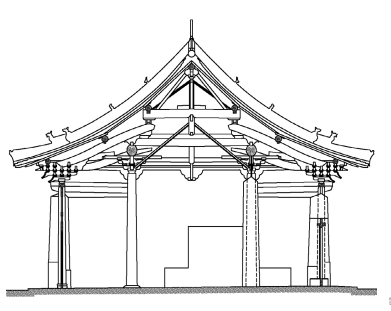

Fig.10 Guangsheng shang temple front hall sectional view

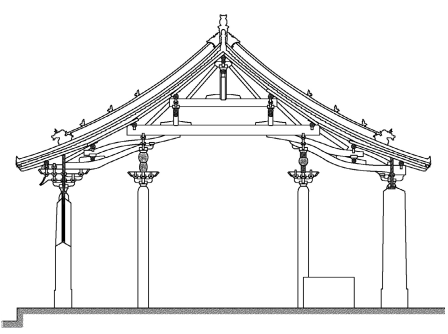

Fig.11 Guangsheng xia temple main hall sectional view
用いるものがある。一つ目は、主屋の屋根裏中央の梁行方向に合掌 型に組む太い斜材 (仮称 : 大型登梁) を用いるもので、前方の身舎 柱上の桁行の大虹梁中央から上方の棟木に架け、主屋の母屋桁の荷 重を受け、これを主屋中央部に 1 挺乃至 2 挺架け渡すものである (Photo7)。これは、前述のように三間堂の正面中央柱間を広く取っ たため、大型登梁が主屋屋根の桁行中央部を支持する「中備」の役 割を担っていることが分かる。二つ目は、庇の屋根裏において、側 柱上の斗栱の尾垂木尻を直材とするのでなく、湾曲材（仮称：小型 登梁）を用いるものである。この小型登梁は、尾垂木尻が変化した ものと考えられる。本来、尾垂木は軒先の荷重を支える挺子の役割 を果す部材であり、尾垂木尻はその後半部分にあたるが、ここでは 尾垂木尻の取付き部分の幅を広げて斗栱と一体化し、構造的な強化 を計り、さらに尾垂木尻の後端を支持する母屋桁との接合部の高さ
に対応させるために湾曲材としている。そのため、尾垂木尻は軒の 桁を支える挺子の機能を残しつつ、高さの異なる部材を繋ぐ登梁の 形状へと変化したものと考えられる。この小型登梁には 2 種類があ り、前述の庇二架系の遺構では母屋桁 2 架を支えるもの (Photo8)、 庇一架系の遺構では母屋桁 1 架を支えるもの(Photo9) がある。

一方、中国の元代以前の遺構の中から、登梁状の部材を眺めると、 管見では山西省の広勝上寺前殿 (Fig.10) 注 17)、下寺後大殿 (洪洞県、

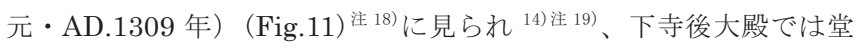
背面の斗栱の手先を一手減ずるなどの点を合わせてみると、華北地 方の元代の構法が四川省に流入した可能性があり、華北中西部から 四川地方に見られる地域的な特性を示すものと考えられる。

そこで、20 棟の中から、先ず登梁の構法を用いたものについて眺 めてみよう。一つ目の大型登梁は元代の遺構 5 棟に見られ、この中 には 1 挺用いるもの（2. 青龍寺大殿、3. 報恩寺三清殿、5.五龍廟文昌 閣)、2 挺用いるもの (1. 花林寺大殿)、さらに大型登梁の上端を棟木 でなく、その下方の母屋桁に架けて、主屋屋根の 2 架を支えるため に 1 挺用いるもの（4.永安寺大殿）がある。これらは、主屋の両妻 に二重虹梁・大瓶束を用いながら、中央部に登梁を用いたことで、 構造的な補強を行うとともに、主屋の内部空間に開放感・上昇感を 生み出している。二つ目の小型登梁は三間堂の庇部分において、側 柱上と中備の斗栱に用いられており、二架系のものでは 2 棟（2.青 龍寺大殿、3. 報恩寺三清殿)、一架系のものでは 9 棟 (1. 花林寺大殿、 5.五龍廟文昌閣、6.百福院前殿、7.盤陀寺大殿、9.開禧寺大雄殿、 11 . 
尊勝寺大雄宝殿、13.龍居寺中殿、15.宝梵寺大雄宝殿、19.豆吒寺正 殿）に見られ、いずれも斗栱の最上段に尾垂木前方を折り曲げて組 み入れ、前端を持出梁のように差し出し、軒の出を支えている。し かも、庇部分に湾曲材を用いたことで、主屋部分の空間全体の上昇 感を高める効果を生んでいる。

さらに、直線的な尾垂木尻について眺めると 7 棟に見られ、いず れも三間堂の庇部分の柱上斗栱と中備斗栱に用いられ、側柱上の斗 栱から 1 架延すのが一般的である（永安寺大殿、饒益寺大雄宝殿、 開善寺正殿、梓潼宮大殿は一部省略)。中には、三間堂の前面のみ用 いるもの (尊勝寺大雄宝殿、河沙寺大雄宝殿)、庇部分を 2 架とし て、側柱上の斗栱加ら 1 架目に直材の尾垂木尻、2 架目に小型登梁 を用いるものもある (甘泉寺大雄宝殿)。このように、直材の尾垂木 尻も一部残され、古来の尾垂木の伝統が継承されていることが分か る。

\section{5. 結論}

本稿では、四川省の元・明代の三間堂 20 棟を取り上げ、それらの 平面寸法、構造システム、斗栱、登梁などの建築的な特質について 検討した。その特徵は、次のように纏められる。

\section{1)、三間堂の外観と平面について}

三間堂の外観は、入母屋造・瓦莫として正面に緩やかな軒反りを 見せ、正面では中央間に両開き扉を入れる。両側背面では大壁式 (3 棟）のもの、真壁式 (17 棟) とするものがある。平面は、桁行 3 間、 梁行 3 間乃至 4 間とし、 1 辺を $12 \mathrm{~m} \sim 15 \mathrm{~m}$ 程の正方形とするのが 一般的である。柱間寸法は、正面（桁行）では中間を脇間の 2.0 倍 〜 3.0 倍程にとるものが多く、側面 (梁行) では、3 間のものは正面 柱間とほぼ同様にとり、4 間のものは正側面の中間を広くとり、側 面中間の中央に柱を立てて中間 2 間とし、堂内の主屋に広い内部空 間を生み出している。また、三間堂の側面 3 間と 4 間の中には、前 方柱間を広くとるものがあり、元代の三間堂では、正面の 1 列目柱 間を吹放す傾向が認められる。

2)、間架と架構について

三間堂の構造は、柱上に斗栱を置き、柱間に繋梁と束を用いて小 屋を組む抬梁式を基本とし、華北・華中地方の架構形式に属してい る。内部空間は主屋に身舎柱 4 本を立て、周囲に柱間 1 間の庇を巡 らしており、庇部分では母屋桁の「間架」を基準に分類すると一架 系、二架系之三架系の 3 種に分かれ、身舎柱 4 本から桁・梁・隅行 3 方向に繋梁を渡し、二架、三架系では 2 重、3 重に繋梁を渡し、 大瓶束を立てて母屋桁を支える。主屋部分では、棟木の前後を合わ せた間架を分類すると、三架系、四架系、五架系 3 種に分けられ、 三間堂の間架と架構は、庇が二架系、主屋が四架系とするのが一般 的である。但し、建物の間架寸法は必ずしも統一されていない。

3)、斗栱と中備について、

三間堂には、三手先・二手先・一手先・持出梁の 4 種類の斗栱が 側柱に用いられ、三間堂の大半が正側背面に載る斗栱を異にしてい る。斗栱配列は 1）正面に三手先、両側背面に三手先・二手先・一 手先・持出梁を用いるもの、2）正面に二手先、両側背面に二手先・ 一手先・持出梁を用いるもの、3）三手先を 4 面用いるもの、4）二 手先を 4 面用いるものがある。これらの斗栱配列の内、3)、4）で は、一つ建物の正側背面に同じ手先の斗栱を使うため、斗栱を支え
る側柱高は均一であるが、1）、2）では三間堂の側面において斗栱の 種類により、高さ、手先の違いを補正する必要があり、高さの違い は柱高、手先の違いは肘木の長さを変えることで対応している。ま た、正面柱間では、中間を脇間の 2 倍 3 倍にとるため、中間に詰 組を 3 具〜 4 具入れることで正面性を高めている。

4)、登梁と尾垂木尻について

三間堂の中には、主屋と庇に湾曲材（登梁）を構造材として用い るものがある。一つは、主屋の屋根裏中央の梁行方向に合掌形に組 む太い斜材（仮称：大型登梁）を用いるもので、前方の身舎柱上の 桁行の大虹梁中央から上方の棟木に架けられ、主屋の母屋桁の荷重 を受け、これを主屋中央の前後に架け渡すものであり、元代の遺構 に用いられている点が注目される。また一つは、庇の屋根裏におい て、側柱上の斗栱の尾垂木尻を角材と寸るのでなく、湾曲材（仮称： 小型登梁）を用い、斗栱と母屋桁を繋いでいる。このように、主屋 部分と庇部分に大型・小型の登梁を用いた点が注目され、構造的な 強化とともに、高く、上昇感のある内部空間を生み出している。

\section{参考文献}

1) Peng, Z. and Wang, X. and Zhu, Z. and Matsueda, S. (translation): Syo kuheki·Katei Tojyou Kiryaku•Yousyuu jyuujitsuki, Heibonsha, 1999. 6 (in Japanese)

彭遵泗，王秀楚，朱子素，松枝茂夫 (訳)：蜀碧・嘉定屠城紀略・揚州十日 記，平凡社，1965.2

2) Sun, X.: Jiangxi and Huguang People and Sichuan in Ming and Qing Dynasties, Sichuan University Press, 2005. 10 (in Chinese) 孫暁芬：明清的江西湖広人與四川，四川大学出版社，2005. 10

3) National Cultural Heritage Administration: The Atlas of Chinese Cultural Relics (Sichuan Volume), Cultural Relics Publishing House, 2009. 9 (in Chinese) 国家文物局編：中国文物地図集 (四川分冊)，文物出版社，2009。9

4) Sichuan Construction Committee, Sichuan Province Exploration and Design Association, Sichuan Civil Engineering and Architecture Society: Ancient Chinese Architecture in Sichuan, Sichuan Science \& Technology Press, 1992. 6 (in Chinese)

四川省建設委員会，四川省勘察設計協会，四川省土木建築学会編：四川古 建築，四川科学技術出版社，1992.6

5) Qing, F. (compile): Historical Architectural Map of Sichuan \& Chongqing, Tsinghua University Press, 2016. 12 (in Chinese)

青峰, 他 (編)：四川重慶古建築地図, 清華大学出版社, 2016. 12

6) Sichuan Provincial Cultural Relics and Archeology Research Institute: Sichuan Ancient Building Surveying and Drawing Set (Volume 1 to 3), Science Press, 2010. 12, 2012. 3, 2013. 11 (in Chinese) 四川省文物考古研究院編：四川古建築測絵図集 $(1 \sim 3)$, 科学出版社，2010。 12, 2012. 3, 2013. 11

7) Chen, Y. and Tian, K. and Zhang, X. (compile): Sichuan Ancient Architecture, Chinese Ancient Architecture Series, China Architecture \& Building Press, 2015. 12 (in Chinese) 陳穎, 田凱, 張先進, 他 (編) : 四川古建築, 中国古建築從書, 中国建築工 業出版社, 2015. 12

8) Zhu, X.: Analysis of Architectural Age and Structural Characteristics of Yongan Temple Main Hall in Langzhong, Sichuan Cultural Relics, No. 1, 1991, pp. 67-69, Sichuan Cultural Relics Editorial Department, 1991. 1 (in Chinese)

朱小南：闑中永安寺大殿建築時代及構造特征浅析, 四川文物, 1991 年, 第 1 期，pp. 67-69，四川文物編輯部，1991. 2

9) Cai, Y. and Zhao, Y. and Zhang, Y.: The Main Hall of Hualin Temple in the New Discovered Yuan Dynasty Architecture in Yanting, Sichuan, Cultural Relics, pp. 75-91, Cultural Relics Publishing House, 2017. 11 (in Chinese) 蔡宇琨，趙元祥，張宇：四川塩亭新発現的元代建築花林寺大殿，文物，pp 
75-91, 文物出版社, 2017. 11

10) Yan, J. and Zhang, Y.: Investigation on the Qinglong Temple in Lushan, Sichuan Province, New Investigation Report on Fields, Archicreation, pp. 342-346, Tianjin University Press, 2011. 11 (in Chinese) 閻金強，張宇：四川蘆山青龍寺大殿調查記，田野新考察報告，建築創作， pp. 242-244, 天津大学出版社, 2011, 11

11) Zhu, X.: Zunsheng Temple in Santai, Sichuan Cultural Relics, No. 6, 1991, pp. 67-68, Sichuan Cultural Relics Editorial Department, 1991. 1 (in Chinese)

景竹友：三台尊勝寺, 四川文物, 1991 年, 第 6 期, pp. 67-68, 四川文物 編輯部, 1991. 11

12) (Song. D) Li, J.: Ying Zao Fa Shi (Volume 1 and 2), Zhejiang People's Fine Arts Publishing House, 2013. 10 (in Chinese)

(宋) 李誡：営造法式(下・上), 浙江人民美術出版社, 2013. 10

13) Takeshima, T.: The Study of the Ying Tsao Fa Shih, total 3 volumes, Chuo Kouron Bijyutsu Shuppan, 1971. 12 (in Japanese)

竹島卓一：営造法式の研究，全三冊，中央公論美術出版，1971。12

14) The Institute for the History of Natural Sciences, Chinese Academy of Sciences: History of Chinese Ancient Architectural Technology, Science Press, 1971. 12 (in Chinese)

中国科学院自然科学史研究所主編：中国古代建築技術史, 科学出版社, 1985. 10

注

注 1) 四川省の三間堂については、「䦭中永安寺大殿建築時代及構造特征浅析」、 「四川塩亭新発現的元代建築花林寺大殿」、「四川蘆山青龍寺大殿調查記」、 「三台尊勝寺」(参考文献 8) 〜11) ) があるが、いずれも個別の報告であり、 同省の遺構を俯瞰して評価したものはない。この中には各建物の沿革・図 面等の記載があるものもあるが、資料が限られるため、これら 4 件につい ても史料・遺構の現地調査を行い、図面作成をして、それらを基に分析・ 検討を行った。

注 2) 89 棟は、元・明代の三間堂 20 棟、五間堂 6 棟、裳階付仏殿 19 棟、天王 殿 1 棟、その他 7 棟、清代の三間堂 12 棟、五間堂 6 棟、七間堂 3 棟、裳階 付仏殿 7 棟、天王殿 4 棟、その他 4 棟である。この中から、今回は元・明 代の三間堂 20 棟を取り上げて分析・検討している。

注 3) 杉野丞・沢田多喜二・曹毅「中国西南地方の寺廟建築の研究 $(1) \sim(10) 」$ 、 (1) ・ (2) 日本建築学会大会学術講演梗概集 $\cdot 2000$ 年 9 月、（3）同上梗概 集・ 2001 年 9 月、(4) ・ (5) 同上梗概集・ 2010 年 9 月、(6) ・ (7) 同上梗概 集・ 2011 年 8 月、(9) ・ (10) 同上梗概集・ 2019 年 9 月、(8) 日本建築学会 東海支部研究報告集 57 号・ 2019 年 2 月。

注 4) 柱間寸法については、四川省の元〜明代の尺寸を用いるべきであるが、 建物毎の尺寸の地域差・施工誤差・経年誤差などを勘案し、実測寸法を尺 換算とせず、メートル法を用いることとした。

注 5) 各建物の上下二段の記載は、上段に実測寸法・下段に寸法比率を示し、 柱間寸法の比率は桁行では左脇間、梁行は前方の寸法を基準(1.0) とした。 なお梁行の下段には間架（母屋桁の間隔数を示した）。

注 6)脇間は、左右両脇間があるが、ここでは左脇間を基準とした。これは、 実測寸法を扱ったためである。

注 7) 注 6)で述べたように右脇間 : 中間の比率を求めると、約 1.4 倍（2 棟）、 約 2.0 倍 $(10$ 棟)、約 2.6 倍（3 棟）、約 3.0 倍（5 棟）となり、左脇間：中 間の比と同等の結果が得られた。

注 8) 20 棟の身舎柱と側柱の柱径について、平均值を求めると、身舎柱約 440 $\mathrm{m} \mathrm{m}$ 、側柱約 $370 \mathrm{~mm}$ となる。但し、同一建物内でも不揃いで不一致のもの が多いため柱間との関連を求めてない。

注 9) 四川省の三間堂の正面柱間の脇間 : 中間 : 脇間の比率の特徵を検証する ために、華北・華中・華南地方の事例を取り上げることとし、宋代から明 代の三間堂 11 棟についてみると、華北地方では、少林寺初祖庵大殿（宋・ 河南省登封） $1: 1.34: 1$ 、青蓮寺大殿（北宋・山西省晋城） $1: 1.31: 1$ 、龍 門寺大殿（宋・山西省平順） $1: 1.38: 1$ 、永寿寺雨花宮 (宋・山西省榆次) $1: 1.14: 1$ 、広勝寺前殿（元・山西省洪洞） $1: 1.71: 1$ である（出典： 「中国古代建築史一宋・遼・金・西夏建築一」中国建築工業出版社、2003 年 刊、「中国古代建築技術史」科学出版社、1985 刊)。華中地方では、保国寺 大殿 (宋・浙江省寧波) $1: 1.93: 1$ 、天寧寺大殿（元・浙江省金華） $1: 1.88$ : 1、真如寺正殿（元・上海市真如） $1: 1.61: 1$ 、楊湾廟正殿（元・蘇州呉県） $1: 1.35: 1$ である (出典:「中国古代建築技術史」中国科学院自然科学史研 究所編、科学出版、1985 年刊、関口欣也「中国両浙の宋元古建築 (1) (2)」
仏教芸術、昭和 59 年 7 月、同年 11 月刊)。華南地方では、華林寺大殿（宋・ 福建省福州） $1 ： 1.41 ： 1$ 、陳太尉宮大殿（宋・福建省羅源）1：1.69：1、方 広岩寺大雄宝殿（明・福建省永泰） $1: 2.00: 1$ である（出典：杉野丞・沢 田多喜二「中国華南地方の建築の研究（1）～（15）」：(1) 日本建築学会東 海支部研究報告・1992 年 2 月、（10）日本建築学会東海支部研究報告集 35 号・1997 年 2 月、（14）日本建築学会大会学術講演梗概集・1998 年 9 月)。 以上のように、管見では、華北・華中・華南の宋代から明代の三間堂の正 面柱間の比率は $1: 1.14 \sim 2: 00: 1$ となり、中間が $2: 00$ 以上のものは少 ないことが分かる。

注 10) 中国の寺廟建築の大壁式は、木造軸組の柱列を包むように煉瓦（磚）の 厚い壁で柱上まで覆うもので、柱頂の斗栱は外に見せる。

注 11) 中国の寺廟建築の真壁式は、日本の真壁のように貫・竹木舞の土壁とせ ず、木造軸組の柱間に煉瓦（磚）を充填させ、外に柱を見せている。

注 12) 20 棟の大半が身舎柱と側柱（頭貫位置）を繋梁で結び、その上部でも 身舎柱と側柱上の斗栱とを結び固有の架構形式をみせているため、ここで は上部の繋虹梁を扱っている。

注 13) 一架 ・二架 ・ 三架系の分類については、20 棟の中には正側背面の間架 数が異なるものがある（正背面一架・両側面二架、正面二架・両側背面一 架、正面三架・両側背面二架)。それらは、身舎柱の柱列を前後、左右に移 したことで狭い間架を生じさせたものが多いため、それらについては、正 側背 4 面の内、2 面或いは 3 面に用いられた間架数を分類の規準とした。

注 14) 擬似尾垂木は、本来の尾垂木の力学的な役割をもつことなく、斗栱の先 端に尾垂木端に似せた突出材を差し出すもので、肘木先端に取り付け、意 匠的な豪華さを得ようとしたものである。

注 15) 真昂尾垂木は、屋根の軒を支えるために斗栱の上段に堂内部から外部 に向けて差し出された直材（尾垂木）であり、斗栱を支点として前端で軒 先を押し上げ、後端を梁・母屋桁等で受けるものである。これに対し、元・ 明代には堂内部から外部に延された直材の後半部分を尾垂木尻として残し 前半部分は斗栱を支点とし、直材を折り曲げて梃子状に扱うことで軒先を 支えるものが仮昂尾垂木である。

注 16)花林寺大殿側面の斗栱立面図は復元図面である。

注 17)Fig. 10 は、参考文献 14), pp. 115, 図 5-7-17, 「山西洪洞広勝上寺前殿横 断面図」と現地調查を基に筆者が図面を作成した。

注 18)Fig. 11 は、参考文献 14), pp. 112, 図 5-7-8, 「山西洪洞広勝下寺後大殿 東稍間横断面図」と現地調査を基に筆者が図面を作成した。

注 19）田中淡博士は「中国建築史の研究」（弘文堂, 平成元年 7 月 10 月刊）の 中で、華北地方の建物に用いられた登梁状の材を取り上げられている。ま た、河北正定隆興寺轉輪蔵殿の内部では柱間を繋ぐ斜材が用いられるが、 これは柱間の梁材であり、本稿で扱う登梁とは部材の役割が異なる。 


\section{A STUDY ON THE BUDDHIST BUILDINGS OF THREE BAY TYPE IN SICHUAN PROVINCE, CHINA IN YUAN AND MING DYNASTY}

\section{Yi CAO ${ }^{* 1}$, Noboru SUGINO *2, Takiji SAWADA*3, Yunzhang $L I^{* 4}$ and Yeqian $Z H A N{ }^{* 5}$}

\footnotetext{
${ }^{* 1}$ Grad. Student, Dept. of Production and Construction Engineering Course, Graduate School of Engineering, Aichi Institute of Technology, M.Eng. ${ }^{* 2}$ Prof., Dept. of Architecture, Aichi Institute of Technology, Dr.Eng.

${ }^{* 3}$ Lect., Dept. of Architecture, Aichi Institute of Technology

${ }^{* 4}$ Prof., Dept. of College of Architecture \& Environment, Sichuan University, Dr.Eng.

${ }^{* 5}$ Lect., College of Landscape Architecture, Nanjing Forestry University, Dr.Eng.
}

In this paper, we took up 20 buildings of Three bay building type from the Yuan and Ming Dynasty in Sichuan Province, and examined their architectural characteristics such as their plane dimensions, structural system, tokyou and climbing beams. The characteristics are summarized as follows.

1) About the appearance and plane of Three bay type

Three bay type is generally constructed as a built-up roof tile, with double doors in the middle at the front and thick wall (3 buildings) and thin wall (17 buildings) on both sides and back. The general plane is between the purlin 3 spans and between the crossbeam 3 or 4 spans, and is a square with a side length of about 12 meters to 15 meters. As for the inter-column dimensions, the ratio between the center and side of the front is about 2 to 3 times.

2) About the span and frame

Three bay type is based on a girder type in which a tokyou is placed on the pillars and a frame is built using beams and bundles between the pillars. It belongs to the frame form of North and Central China. The interior space has four pillars in the center and eaves with a width of 1 is surrounded around it. In the eaves, it is divided into three types, one-frame, two- frame, and three-frame system, based on the purlin girder span. The Moya is divided into three types, three-frame, four-frame and five-frame. It is common for Three bay type to have a two-frame system for the eaves and a four-frame system for the Moya.

3) About the tokyou and center-tokyou

In Three bay type, there are four types of tokyou, 3-stage, 2-stage, 1-stage, and overhanging beam, there are different from the ones on the front, both sides and back. The tokyou arrangement have 4 types. The first one uses a 3 -stage on the front and 3-stage, 2-stage, 1-stage, overhanging beam on the both sides and back. The second one uses a 2 stage on the front and 2-stage, 1-stage, overhanging beam on the both sides and back. The third one uses a 3 -stage on the front, both sides and back. The fourth one uses a 2 -stage on the front, both sides and back.

4) About the climbing beam and the tail rafter of Tokyou

Some buildings of Three bay type use curved materials (climbing beams) as structural materials for the Moya and eaves. One is to use a thick diagonal material (tentative name: large climbing beam) assembled in the shape of a palm in the beam direction in the center of the attic of the Moya. The other is to use a curved material (tentative name: small climbing beam) for the tokyou on the side pillar, which connect the tokyou to the Moya girder in the attic of the eaves. 